\title{
Land snail communities respond to control of invasive rats in New Zealand forests
}

\author{
Gary M. Barker \\ Landcare Research, Private Bag 3127, Hamilton, New Zealand \\ Present address: PO Box 108, Meeniyan, Victoria 3956, Australia \\ (Email: barkerg@landcareresearch.co.nz)
}

Published online: 3 June 2016

\begin{abstract}
While invasive rats are demonstrably inimical to indigenous vertebrate species, there has not been unequivocal evidence of benefit to invertebrate communities from management of these invasive mammals in New Zealand forest systems. The present study examined the response of land snail communities to intensive management of ship and Norway rats by sampling paired rainforest blocks, one block of which had been subject to intensive management of rats, while the other block had been without management of invasive rats and thus subject to ambient rodent infestations. Rat tracking index data indicated rat management regimes were generally effective in reducing rat abundance relative to non-treated forest blocks. At the whole community level there was little evidence that forest management regime influenced the structure of land snail communities. However, when only the larger-shelled ( $\geq 4 \mathrm{~mm}$ maximum shell dimension) component of the communities was considered, strong effects of rat management regime were evident with increased land snail abundances, species richness and functional trait values. These results are discussed in relation to potential direct and indirect of effects of management regimes that reduce rat abundance.
\end{abstract}

Keywords: conservation; invertebrates; mammal control; New Zealand; Norway rat; Rattus; rodents; ship rat

\section{Introduction}

Since the Middle Miocene the New Zealand terrestrial biota evolved free of the influence of nonvolant mammals (Worthy et al. 2006). A product of such an evolutionary setting is a biota naïve to the search and prey handling strategies of ground-dwelling mammalian predators (Gibbs 2009, 2010) introduced with human visitation and settlement commencing with predecessors of the Māori about 750 years ago (Wilmshurst et al. 2008). Among the 34 mammals introduced to date are a suite of predators with important ecological impacts in New Zealand indigenous ecosystems, including dogs, cats, stoats, ferrets, weasels, and four rodents that comprise the house mouse, Pacific rat, ship rat and Norway rat (Atkinson 2001; Blackwell 2005). The Pacific rat (Rattus exulans) probably accompanied the first travellers to New Zealand and available evidence indicates rapid pervasive colonisation from sea level to the sub-alpine zone (Atkinson 2001). Norway rat (Rattus norvegicus) accompanied the first European visitors to New Zealand from 1769 and also extensively colonised the main islands. Ship rat (Rattus rattus) introduction was much later, evidently around 1860-1870, but despite earlier dominance by Pacific rat and then Norway rat, it is this species that now predominates in forest systems in mainland New Zealand (Innes 2005). Among the introduced mammals, it is these Rattus species that have been considered the most damaging to the New Zealand terrestrial invertebrate biota (Ramsay 1978; Buckley et al. 2015). Nonetheless, while alien mammals are widely recognised as inimical to indigenous vertebrate species, the effects on indigenous invertebrates are still poorly understood. While there are documented cases of extinction in large bodied invertebrates that have been attributed to rodent predation (Kuschel \& Worthy 1996; Gibbs 1998; Leschen \& Rhode 2002; Leschen et al. 2012; Buckley et al. 2015), for the most part the indigenous invertebrate fauna has suffered few known extinctions since human colonisation of the New Zealand archipelago (Stringer \& Hitchmough 2012). However, it is possible that sustained predation by rodents over several centuries has substantially modified invertebrate community structure, with reduced range and abundance in species whose population dynamics are vulnerable to perturbation through imposition of novel levels and forms of predation and shifts in resource availability (Ramsay 1978). It is even possible that sustained effects of rodents over several centuries has led to high levels of cryptic extinction and new states of equilibria, with predominately disturbance-tolerant species persisting in communities, such that rodent removal is now unlikely to lead to observable ecological release.

Rats are intensively managed at an increasing number of sites throughout mainland New Zealand with the objective of restoration of indigenous communities and ecosystems (Saunders \& Norton 2001; Campbell-Hunt 2008; Peters et al. 2015; Russell et al. 2015). While Craddock (1997), Hunt et al. (1998), Green (2002), Rufaut and Gibbs (2003), Watts (2004), Sinclair et al. (2005), King (2007), Ogden and Gilbert (2009), Rate (2009), Ruscoe et al. (2013), Watts et al. (2014) and others have provided information on the response of invertebrates to management of forests to reduce rat abundance, the evidence for rats being important drivers of community structure in contemporary New Zealand forests remains very weak. Watts et al. (2014) suggest five possible reasons for insubstantial change in invertebrate communities in ecosystems released from mammal predation, namely: (i) pest mammal species may not regulate extant indigenous invertebrate populations; (ii) residual mammal species/densities may continue to suppress invertebrate communities; (iii) increased densities in indigenous insectivorous birds, in response to pest mammal control, suppress invertebrate communities; (iv) there may have been insufficient time for changes to develop. The first scenario is perhaps the null hypothesis - that predatory mammals such 
as rats have not imposed mortality that cannot be replaced by other regulatory agents (irreplaceable mortality sensu Thompson 1955; Morris 1965) sufficient to drive changes in indigenous invertebrate population dynamics and regulation.

In this work, I examine the response of land snail communities to intensive management of ship rats in New Zealand broadleaf rainforests. The hypothesis is that if predation by rats is presently important in the ecology of land snails, rat control should lead to ecological release that in turn should be evident in changes in the structure of land snail communities. This work was undertaken as a prelude to more detailed examination of the impact of predation by rats on the population dynamics of individual land snail species.

\section{Materials and methods}

\section{Experimental design}

At nine locations in New Zealand, land snail communities were sampled in paired rainforest blocks, one block of which had been subject to intensive management of invasive rats (treated), while the other block had been without management of invasive rats and thus subject to ambient rodent infestations (nontreated). These treated and non-treated blocks were located within 2-6.5 km of each other and of similar topography and vegetation type (see Table S1 in Supplementary Material). All treated forest blocks were under the management of the New Zealand Department of Conservation (DOC) or by local community groups under guidance from DOC, had the objective of native biodiversity restoration, and employed recognized rodent management protocols that involved aerial application of baits containing 1080 (sodium monofluroroacetate) and/ or continuous ground baiting with a rodenticide (variously Diphacinone, Racumin, Pindone) and trapping on a grid pattern throughout the forest. Rat populations have been observed to decline rapidly (more than 90\%) within 2-3 weeks of aerial 1080 operations (Innes et al. 1995). However, the recovery of rat populations to precontrol levels within 2-5 months of a 1080 control operation has been noted by several authors (e.g. Warburton 1989; Innes \& Williams 1991) and thus management of forests to maintain low rat abundance is dependent on ongoing control using trapping and/or rodenticides available at bait stations. The nine locations were selected from a suite of candidate sites at which intensive rat management was being undertaken primarily on the grounds that: (i) management of rats had been in place for at least five years; and (ii) nontreated forest was available in the vicinity that could serve as an appropriate control. The size of the treated forest blocks varied: Trounson 800 ha; Waitakere 1100 ha; Moehau 3000 ha; Te Urewera 1000 ha; Ruakuri 160 ha; Whareorino 300 ha; Boundary Stream 800 ha; Pukawa 50 ha; Takaka 18 ha. The locations collectively provided a gradient of ecosystem productivity, with a range of latitude (35.7264 to $\left.40.9404^{\circ} \mathrm{S}\right)$ and elevation (140 to $768 \mathrm{~m}$ ). Queries of $100 \mathrm{~m}$ resolution surfaces interpolated from meteorological station climate data (30-year period 1950-80) (Leathwick \& Stephens 1998) indicated varied macroclimatic conditions across the locations, with mean annual temperature ranging from $8.7^{\circ} \mathrm{C}$ to $14.1^{\circ} \mathrm{C}$ and mean annual rainfall ranging from 1350 to $2700 \mathrm{~mm}$.

\section{Land snails as a focal taxon}

The New Zealand land-snail fauna is well studied and among the most species-rich in the world, with approximately 1400 species (Barker \& Mayhill 1999; Barker 2005). The alpha diversity of land snails in forest sites is also very high, with communities of 30-70 species occurring within areas of only a few square metres (Barker \& Mayhill 1999; Barker 2005). These patterns of diversity, along with the limited mobility and sensitivity to habitat disturbance (Lydeard et al. 2004; Douglas et al. 2013), and ease of sampling make them an ideal choice among invertebrates for this type of study. Despite recognition of predation by rats as a threatening process in populations of some larger iconic species, the role of rats in structuring land snail communities has not been previously studied in New Zealand forests.

\section{Land snail sampling}

Land snail communities were sampled quantitatively at five plots in each treated and non-treated forest block on a single occasion during April-May (autumn) 2008. The plots, each c. $20 \times 20 \mathrm{~m}$ and separated by at least $100 \mathrm{~m}$, were selected by a random walk within the core of the treated forest (to avoid margins of the treatment areas that may be most strongly affected by rat reinvasion), and a walk through the nontreated block with like elevation, topography and vegetation. Standardised sampling effort was applied per plot through a combination of two complementary approaches to sampling litter-associated land snails on the forest floor (Barker 2005): (i) collections by hand and 'spooning' of litter and humus across the extent of the plot from micro-sites favourable for live animals and the accumulation of 'dead-shell' assemblages. These micro-sites generally comprised the base of trees or rocks, the undersides and upper surfaces on small logs and other woody debris, crevices among talus boulders, and particularly deep accumulations of litter amongst ground cover vegetation and under fallen palm and tree-fern fronds. At the plot level this litter and humus material amounted to 2-4 litres. (ii) Defined area sampling by collection of litter and associated humus from ten $33 \mathrm{~cm}$-diameter circular frames $\left(0.086 \mathrm{~m}^{2}\right)$ placed randomly within the plot. The high intensity of sampling sought to yield high numbers of specimens per forest block to maximise ability to detect treatment effects on the land snail communities.

The litter and humus collections from both methods were placed directly into cloth bags in the field and on return to the laboratory slowly and completely dried in an oven at $50^{\circ} \mathrm{C}$. Dried samples were partitioned by dry sieving, with the coarse fraction retained by a $10 \mathrm{~mm}$ mesh examined by eye for larger shells and the fine fraction retained by a $0.5 \mathrm{~mm}$ mesh examined under a stereomicroscope. All shells, including those of juveniles, were identified to species with reference to authoritatively-identified material (including vouchers for undescribed species) held in the Museum of New Zealand Te Papa Tongarewa(MNZ) andAuckland Museum. Nomenclature was standardised to that used by Spencer et al. (2009). For all specimens recovered from samples the shell height and width were measured with either an ocular micrometre affixed to a Wild M7A ${ }^{\mathrm{TM}}$ stereomicroscope or with General ${ }^{\mathrm{TM}}$ callipers. Furthermore, all individuals in the samples were classified as either 'live-collected' or 'dead-collected'; that a particular snail was alive at the time of collection was indicated by the presence of dried animal tissues within the shell.

\section{Index of rat abundance}

The relative abundance of rats in the treated and non-treated forest blocks was monitored using animal tracking tunnels 
(King \& Edgar 1977; Gillies \& Williams 2013) following the national guidelines (see Gillies \& Williams 2013 for version chronology and current guidelines). The technique employs a 'run through' tunnel containing two pieces of card either side of a pad coated or soaked with ink. As an animal passes through the tunnel it picks up the ink on its feet, then as it departs from the tunnel it leaves a set of footprints on the cards. Tracking tunnels were set on randomly orientated lines, and animal visitations recorded as the average percentage of tunnels containing rat tracks - hence forth referred to as rat tracking index (RTI). RTI provides only a coarse index of relative abundance of rats; it is not a direct measure of population density as the index can be influenced by variation in activity. The technique is best suited for providing simultaneous comparisons of the relative abundance of rats between similar habitat areas and gross changes in relative abundance over time at a single site. Sources of RTI data are given in Table S3 in Supplementary Material.

\section{Analyses}

To avoid issues of pseudoreplication, data for the five plots were pooled to provide a single, robust estimate of land snail community structure within treatment blocks within each location. Abundance was expressed as the total number of snail individuals recovered for the five plots. The functional composition of land snail communities was expressed using aggregate, abundance-weighted shell size trait values (Shipley et al. 2006):

$$
T=\sum_{i=1}^{S} x_{i} a_{i}
$$

where: $x_{i}$ is the trait value for species $i, a_{i}$ is its abundance and $S$ is species richness of the community. The functional trait used was shell maximum dimension ( $\mathrm{mm}$ ) (see Table S2 in Supplementary Material) and the aggregate, abundanceweighted values for $T$ referred to community-level functional trait values.

The completeness of land snail community sampling was evaluated in EcoSim7.44 (Gotelli \& Entsminger 2004) using Chaol (Chao 1984; Chao et al. 2005) (and its standard deviation; Chao 1987), a nonparametric richness estimator that has been shown to give reliable estimate, even from relatively small sample sizes (Colwell \& Coddington 1994). For 1000 permutations of the data, Chaol estimates the number of species missed during sampling using the number of singletons and doubletons observed and adds this number to the observed number of species to obtain an estimated total number of species. Percentage sample completeness was calculated as:

$$
C=100 \cdot \frac{S_{O b s}}{S_{C h a o 1}}
$$

where: $S_{O b s}$ is the observed sample species richness, and $S_{\text {Chaol }}$ the Chaol estimate. Representativeness of the samples for the block-level communities was assessed using sample- and individual-based species richness accumulation curves in EcoSim 7.44. Turnover in community composition within and between treatment blocks at each location was estimated as Bray-Curtis (Bray \& Curtis 1957) dissimilarity:

$$
B C=\sum_{i=1}^{P}\left|x_{i j}-x_{i k}\right| / \Sigma_{i=1}^{p} x_{i j}+x_{i k}
$$

where $\mathrm{x}_{\mathrm{ij}}$ and $\mathrm{x}_{\mathrm{ik}}$ arethe abundances for the $i$ th species in the $j$ th and $k$ th sample $(i=1,2, \ldots, \mathrm{p} ; j=1,2, \ldots, \mathrm{n} ; k=1$, $2, \ldots, n)$.
Null model analysis Monte Carlo permutation using EcoSim 7.44 was applied to assess the significance of differences in land snail abundance and community-level functional trait values, and RTI values of rat abundance, between paired treated and non-treated blocks within locations and, where appropriate, treated and non-treatment blocks across all locations. The null model randomizes values between treated and non-treated blocks, with the permutation procedure repeated 1000 times. P-values were calculated as the proportion of simulations giving a value for the test statistic that departed from the observed. Observed paired differences were expressed relative to expected values using Standardized Effect Size (SES) (Gotelli \& McCabe 2002; Leprieur et al. 2012), which is an extension of the familiar Z-score for testing if an individual deviates significantly from the population mean:

$$
S E S=\frac{x_{\mathrm{Obs}^{-x}}{ }_{\mathrm{Exp}}}{\sigma_{\mathrm{Exp}}}
$$

where $\mathrm{x}_{\mathrm{Obs}}$ is the mean value obtained from the observed data, $\mathrm{x}_{\operatorname{Exp}}$ is the mean of the randomisations and $\sigma_{\operatorname{Exp}}$ is the standard deviation across those randomizations.

The potential importance of individual species was simply identified as those contributing $\geq 10 \%$ to any differences between treated and non-treated blocks. Setting the observed values for the species in question to its average across treated and non-treated blocks within location and rerunning the Monte Carlo permutations confirmed that these differences between blocks for these species were the primary driver for rejection of null models.

Null models were also used to compare species richness between paired treated and non-treated blocks within locations. Species richness computed as Chaol (see above) was used to calculate SES as in Equation 2, but where $\mathrm{x}_{\mathrm{Obs}}$ is the value obtained from the treated block, and $\mathrm{x}_{\operatorname{Exp}}$ and $\sigma_{\operatorname{Exp}}$ is the value and its standard deviation obtained from the non-treated block.

All analyses were computed for entire communities and for that subset of species whose maximum shell dimension was estimated at $\geq 4 \mathrm{~mm}$ (as indicated by examination of extensive specimen series in MNZ), and as such hypothesised as that component of communities most vulnerable to predation by rats due to their larger size.

The results for the rat management regime effects presented below are based entirely on the 'live-collected' component of samples as this treatment of samples is less controversial than analyses based on counts that include shells of animals that had died prior to sampling (see Sólymos et al. 2009; Schilthuizen 2011; Yanes 2011; Albano 2014 for discussions). However, it should be noted that: (i) in the moist rainforest environments of New Zealand most shells of dead land snail species degrade rapidly and in most situations are entirely decomposed within 3-6 months (GM Barker, unpubl. data). Thus counts that combine both shells from prior mortality events and 'livecollected' individuals can effectively integrate short-term temporal variability in species occurrence; (ii) in the present work, results are consistent between analyses based entirely on 'live-collected' and those on composite samples (see Tables S3 and S4 in Supplementary Material). On average $73.4 \%$ (range 62-82\%) of individuals obtained in samples were 'livecollected'. The percentage of 'live-collected' individuals did not vary between treated and non-treated blocks (Table S4). 


\section{Results}

\section{Adequacy of land snail sampling}

Sampling yielded 126347 land snail specimens, representing seven families and 254 species (Table S3). All but two species were native to the sampled locations. The number of individuals in samples for each treatment block averaged 7020 (range 3389-11 009) for 'dead-collected' plus 'live collected' snails, and 5270 (2583-8404) for 'live collected' snails (Table S4). Sample- and individual-based species accumulation curves (see Figure S1 in Supplementary Material) exhibited asymptotes in species richness. Such large sample sizes provided for $99 \%$ completeness, as estimated as the ratio of observed to Chao 1 species richness. The ratio of individuals to species averaged 83.6 (32.9-126.5) and thus far exceeded the minimum of 10 recommended specifically for samples from land snail communities by Cameron and Pokryszko (2005). This ratio did not vary significantly between treatment blocks (SES -0.363, $\mathrm{P}=0.484$ ). Bray-Curtis dissimilarity between sites within treatment blocks averaged 0.162 (Table S4). The sampling was thus representative of the community within forest blocks at the nine locations, and our estimates robust to within-treatment community composition and comparisons across the two treatments.

\section{Effects of forest management regimes}

Analyses based on all sampled 'live collected' individuals (Table 1) indicated an absence of treatment effects on land snail abundance. Similarly, analyses restricted to species with specific maxima in shell dimension $<4 \mathrm{~mm}$ indicated an absence of treatment effects on abundance (data not presented). Chaol estimates of species richness tended to be higher in the forest blocks under management to reduce rat abundances, and indeed null models were rejected for four locations (Trounson, Wharerino, Pukawa, Takaka) indicating land snail species richness differed between treatments more than expected by chance. Across all locations, and at the Trounson location, the null models rejected the hypothesis that size of land snail individuals, as measured by mean shell maximum dimension, was independent of forest block management. For the remaining eight locations the observed trend was for a larger mean size of individuals in the forest blocks where rats were managed, but the null models could not be rejected. The communitylevel functional trait values tended to be higher for land snails in forest blocks where rats were managed, but null models consistently indicated chance effects could not be rejected.

A total of 78 species with specific maxima in shell dimension $\geq 4 \mathrm{~mm}$ were identified across the nine locations. When only these larger species were considered, forest block treatment effects were much more apparent (Table 2) than when including all species in the analyses. The null models were rejected and the pattern of community structure was consistent with predictions that management to reduce abundance of rats led to more abundant, and more species rich, larger-shelled land snail communities. Averaged across locations, larger-shelled species were $96 \%$ more abundant, the mean size of individuals increased by $11.5 \%$, and community-level functional trait values increased by $117.8 \%$ in managed forest blocks relative to the non-treated blocks. Chaol estimates indicated managed forest blocks, on average, contained an additional 2.6 species relative to the non-treated forest blocks, although this was not statistically significant.

Table 3 summarises data for those species in the larger-snail category that exhibited the greatest numerical and functional trait responses to forest block treatment. Several species of land snail of concern to conservation managers occurred at the sampled locations, including the Rhytididae Amborhytida

Table 1. Whole community-level abundance, richness and functional trait values for 'live collected' land snails sampled in paired forest blocks at nine locations where ship rat and Norway rat were either intensively managed (T) or not (NT), with SES estimated from null models.

\begin{tabular}{|c|c|c|c|c|c|c|c|c|c|c|c|c|}
\hline \multirow[t]{2}{*}{ Location } & \multicolumn{3}{|c|}{ Abundance } & \multicolumn{3}{|c|}{ Species richness $^{1}$} & \multicolumn{3}{|c|}{$\begin{array}{l}\text { Mean shell } \\
\text { maximum dimension }(\mathrm{mm})\end{array}$} & \multicolumn{3}{|c|}{$\begin{array}{l}\text { Community-level } \\
\text { functional trait values }\end{array}$} \\
\hline & $\mathrm{T}$ & NT & SES & $\mathrm{T}$ & NT & SES & $\mathrm{T}$ & NT & SES & $\mathrm{T}$ & NT & SES \\
\hline Trounson & 4397 & 4546 & $\begin{array}{c}-0.691 \\
P=0.142\end{array}$ & 68.0 & 63.2 & $\begin{array}{c}6.517 \\
\mathbf{P}<0.001\end{array}$ & 2.00 & 1.63 & $\begin{array}{c}-1.546 \\
P=0.042\end{array}$ & 8813 & 7398 & $\begin{array}{c}0.007 \\
\mathrm{P}=0.674\end{array}$ \\
\hline Waitakere & 6081 & 6009 & $\begin{array}{c}-0.844 \\
P=0.162\end{array}$ & 116.0 & 115.7 & $\begin{array}{c}0.095 \\
\mathrm{P}=0.867\end{array}$ & 2.27 & 1.89 & $\begin{array}{c}-0.578 \\
P=0.206\end{array}$ & 13800 & 11370 & $\begin{array}{c}-0.083 \\
P=0.647\end{array}$ \\
\hline Moehau & 4569 & 4793 & $\begin{array}{c}-0.494 \\
P=0.273\end{array}$ & 84.2 & 82.0 & $\begin{array}{c}0.221 \\
\mathrm{P}=0.657\end{array}$ & 2.02 & 1.60 & $\begin{array}{c}-0.785 \\
\mathrm{P}=0.074\end{array}$ & 9242 & 7680 & $\begin{array}{c}-0.135 \\
\mathrm{P}=0.369\end{array}$ \\
\hline Te Urewera & 4477 & 4397 & $\begin{array}{c}-0.772 \\
P=0.164\end{array}$ & 66.0 & 65.0 & $\begin{array}{c}1.000 \\
\mathrm{P}=0.357\end{array}$ & 1.90 & 1.57 & $\begin{array}{c}-0.835 \\
\mathrm{P}=0.213\end{array}$ & 8689 & 7007 & $\begin{array}{c}-0.067 \\
P=0.630\end{array}$ \\
\hline Ruakuri & 7456 & 7850 & $\begin{array}{c}-0.884 \\
\mathrm{P}=0.151\end{array}$ & 92.5 & 91.5 & $\begin{array}{c}0.970 \\
\mathrm{P}=0.327\end{array}$ & 2.07 & 1.70 & $\begin{array}{c}-1.145 \\
\mathrm{P}=0.067\end{array}$ & 15422 & 13340 & $\begin{array}{c}-0.565 \\
\mathrm{P}=0.401\end{array}$ \\
\hline Wharerino & 7792 & 8404 & $\begin{array}{c}-0.977 \\
\mathrm{P}=0.189\end{array}$ & 89.7 & 84.7 & $\begin{array}{c}3.831 \\
\mathbf{P}<\mathbf{0 . 0 0 1}\end{array}$ & 1.82 & 1.58 & $\begin{array}{c}-1.006 \\
P=0.085\end{array}$ & 14156 & 13289 & $\begin{array}{c}-0.947 \\
\mathrm{P}=0.195\end{array}$ \\
\hline Pukawa & 5421 & 6025 & $\begin{array}{c}-0.678 \\
\mathrm{P}=0.282\end{array}$ & 83.0 & 77.5 & $\begin{array}{c}4.158 \\
P<0.001\end{array}$ & 2.00 & 1.75 & $\begin{array}{c}-0.591 \\
P=0.339\end{array}$ & 10830 & 10531 & $\begin{array}{c}-0.792 \\
P=0.069\end{array}$ \\
\hline Boundary Str. & 3650 & 3547 & $\begin{array}{c}-0.713 \\
\mathrm{P}=0.175\end{array}$ & 66.0 & 65.2 & $\begin{array}{c}0.171 \\
\mathrm{P}=0.764\end{array}$ & 1.59 & 1.41 & $\begin{array}{c}-0.157 \\
\mathrm{P}=0.603\end{array}$ & 5793 & 4984 & $\begin{array}{c}-0.533 \\
\mathrm{P}=0.405\end{array}$ \\
\hline Takaka & 2583 & 2877 & $\begin{array}{c}-0.474 \\
\mathrm{P}=0.451\end{array}$ & 97.9 & 90.4 & $\begin{array}{c}8.636 \\
P<0.001\end{array}$ & 2.29 & 2.02 & $\begin{array}{c}-0.654 \\
P=0.132\end{array}$ & 5923 & 5820 & $\begin{array}{c}-0.707 \\
\mathrm{P}=0.084\end{array}$ \\
\hline All locations & 5158 & 5383 & $\begin{array}{c}-0.631 \\
\mathrm{P}=0.205\end{array}$ & 84.8 & 81.7 & $\begin{array}{c}-0.569 \\
\mathrm{P}=0.309\end{array}$ & 2.00 & 1.68 & $\begin{array}{c}5.469 \\
P=0.003\end{array}$ & 10296 & 9046 & $\begin{array}{c}-0.243 \\
\mathrm{P}=0.425\end{array}$ \\
\hline
\end{tabular}

1. Chao1 estimate. 
dunniae (Gray, 1840), Amborhytida forsythi (Powell, 1952), Paryphanta busbyi busbyi (Gray, 1850), Rhytida oconnori (Powell, 1946), and Powelliphanta hochstetteri (L. Pfeiffer, 1862). Because of their low abundance in the samples, these species generally contributed little to sample sizes and thus to null model testing, but observed abundances and species-level functional trait values were in all cases higher in the treated than in the non-treated forest blocks (abundancies: 83.7 vs 30.7; functional trait values 374.7 vs 128.0 , respectively).

Effort expended to assess residual rat abundance in treated forest blocks and ambient rat abundance in nontreated comparison blocks, varied greatly among locations, reflecting the desired outcomes and management objectives of the projects at the respective locations. No RTI data were available for the Takaka location. Available RTI data for the remaining eight locations ranged from a single assessment at Pukawa to 60 assessments over 13 years at Boundary Stream (Table 4). Despite the limitations of sample sizes, the high effectiveness of the rat management regimes in the treated forest blocks was indicated, with $78-100 \%$ reduction in RTI relative to the non-treated blocks (Table 4). Null models were rejected, indicating differences in RTI between treated and non-treated forest blocks were not due to chance effects. Nonetheless, the RTI of non-treated forest blocks could not be taken as a reliable indicator of ecosystem differences among locations in rat abundance as monitoring frequency and timing were not standardised and thus variably accommodated marked seasonal fluctuations in rat densities. Against this background, no relationship could be detected between RTI in the nontreated forest blocks and SES for treatment contrasts of land snail abundance and community-level functional trait values within locations.

\section{Discussion}

As is typical of New Zealand forest systems, the grounddwelling land snail communities at the sampled locations were highly species rich (alpha diversity 49-71 species; block-level diversity 65-116 species), strongly dominated by minute species $(<4 \mathrm{~mm})$ and with a significant component of immature individuals (community mean shell size 1.38 to 2.30 $\mathrm{mm}$ ), but including a few larger species with shells 30-35 mm (exceptionally to $80 \mathrm{~mm}$ ) in maximum dimension. The stronger treatment effect seen in the larger-shelled ( $\geq 4 \mathrm{~mm}$ ) component of the land snail communities provide some positive evidence in favour of release from predation by rats as a mechanism for ecological response in communities of larger-sized land snails. RTI data confirmed that the management regimes imposed in the treated forest blocks were effective in reducing rat abundance. The RTI data also indicated considerable variation in rat abundance in non-treated forests across the locations included in the study, but variable numbers of RTI assessments and inconsistencies in the seasonal spread of those assessments within locations limited ability to detect a relationship between ecosystem-level rat carrying-capacity and effects on land snail communities. Thus, the exact mechanism(s) by which land snail communities might have been impacted by the contrasting management regimes at these locations is as yet unclear as both direct and indirect effects are possible.

The treated forest blocks used in the present study varied greatly in size - 18 to 3000 ha - and thus may have differed in the level and importance of rat reinvasion from neighbouring non-treated forests and other habitat. These forest block area effects were likely most significant at Takaka. Being surrounded by a huge non-treated area of beech forest, the 10 ha treated block at Takaka was likely overwhelmed by rats during irruptive periods associated with beech masts (King \& Moller

Table 2. Abundance, richness and functional trait values for 'live collected' larger land snails (adult shell size $\geq 4.0$ mm) sampled in paired forest blocks at nine locations where ship rat and Norway rat were either intensively managed ( $\mathrm{T}$ ) or not (NT), with SES estimated from null models.

\begin{tabular}{|c|c|c|c|c|c|c|c|c|c|c|c|c|}
\hline \multirow[t]{2}{*}{ Location } & \multicolumn{3}{|c|}{ Abundance } & \multicolumn{3}{|c|}{ Species richness } & \multicolumn{3}{|c|}{$\begin{array}{c}\text { Mean shell } \\
\text { maximum dimension }(\mathrm{mm})\end{array}$} & \multicolumn{3}{|c|}{$\begin{array}{c}\text { Community-level } \\
\text { functional trait values }\end{array}$} \\
\hline & $\mathrm{T}$ & NT & SES & $\mathrm{T}$ & NT & SES & $\mathrm{T}$ & NT & SES & $\mathrm{T}$ & NT & SES \\
\hline Trounson & 691 & 347 & $\begin{array}{c}3.833 \\
P=0.011\end{array}$ & 22.0 & 20.0 & $\begin{array}{c}11.428 \\
\mathbf{P}<0.001\end{array}$ & 5.37 & 4.54 & $\begin{array}{c}6.567 \\
P<0.001\end{array}$ & 3709 & 1576 & $\begin{array}{c}4.424 \\
P=0.005\end{array}$ \\
\hline Waitakere & 1326 & 715 & $\begin{array}{c}3.909 \\
P=0.012\end{array}$ & 32.0 & 30.3 & $\begin{array}{c}2.651 \\
P=0.006\end{array}$ & 4.75 & 4.38 & $\begin{array}{c}4.127 \\
P=0.008\end{array}$ & 6298 & 3132 & $\begin{array}{c}6.479 \\
P<0.001\end{array}$ \\
\hline Moehau & 755 & 249 & $\begin{array}{c}4.178 \\
P=0.005\end{array}$ & 27.5 & 28.0 & $\begin{array}{c}\mathbf{0 . 1 1 3} \\
P=0.904\end{array}$ & 4.85 & 3.92 & $\begin{array}{c}4.431 \\
P=0.005\end{array}$ & 3659 & 975 & $\begin{array}{l}10.108 \\
P<0.001\end{array}$ \\
\hline Te Urewera & 790 & 388 & $\begin{array}{c}3.580 \\
P=0.015\end{array}$ & 18.0 & 17.0 & $\begin{array}{c}2.439 \\
P=0.026\end{array}$ & 4.58 & 4.04 & $\begin{array}{c}4.072 \\
P=0.011\end{array}$ & 3618 & 1568 & $\begin{array}{c}6.629 \\
P=0.002\end{array}$ \\
\hline Ruakuri & 1393 & 657 & $\begin{array}{c}4.348 \\
P=0.008\end{array}$ & 32.0 & 31.3 & $\begin{array}{c}1.175 \\
P=0.325\end{array}$ & 4.82 & 4.50 & $\begin{array}{c}4.155 \\
P=0.009\end{array}$ & 6718 & 2957 & $\begin{array}{c}6.107 \\
\mathbf{P}<\mathbf{0 . 0 0 1}\end{array}$ \\
\hline Wharerino & 1023 & 577 & $\begin{array}{c}2.804 \\
P=0.029\end{array}$ & 37.0 & 33.0 & $\begin{array}{c}11.268 \\
P<0.001\end{array}$ & 4.79 & 4.44 & $\begin{array}{c}4.342 \\
P=0.008\end{array}$ & 4900 & 2564 & $\begin{array}{c}4.157 \\
P=0.009\end{array}$ \\
\hline Pukawa & 886 & 392 & $\begin{array}{c}7.286 \\
\mathbf{P}<\mathbf{0 . 0 0 1}\end{array}$ & 28.0 & 25.0 & $\begin{array}{c}7.792 \\
\mathbf{P}<0.001\end{array}$ & 5.12 & 4.83 & $\begin{array}{c}3.510 \\
P=0.013\end{array}$ & 4538 & 1892 & $\begin{array}{c}8.155 \\
P<0.001\end{array}$ \\
\hline Boundary Str. & 334 & 134 & $\begin{array}{c}3.517 \\
P=0.012\end{array}$ & 22.0 & 16.0 & $\begin{array}{c}14.634 \\
P<0.001\end{array}$ & 4.86 & 4.46 & $\begin{array}{c}4.421 \\
P=0.006\end{array}$ & 1624 & 597 & $\begin{array}{c}4.667 \\
P=0.006\end{array}$ \\
\hline Takaka & 665 & 545 & $\begin{array}{c}-0.345 \\
P=0.475\end{array}$ & 33.0 & 27.0 & $\begin{array}{c}25.000 \\
P<0.001\end{array}$ & 4.47 & 4.04 & $\begin{array}{c}4.696 \\
P=0.004\end{array}$ & 2974 & 2200 & $\begin{array}{c}0.322 \\
P=0.243\end{array}$ \\
\hline All locations & 874 & 445 & $\begin{array}{c}5.311 \\
\mathrm{P}=0.005\end{array}$ & 27.9 & 25.3 & $\begin{array}{c}-0.184 \\
P=0.368\end{array}$ & 4.85 & 4.35 & $\begin{array}{c}6.401 \\
P=0.002\end{array}$ & 4226 & 1940 & $\begin{array}{c}7.455 \\
P=0.002\end{array}$ \\
\hline
\end{tabular}


Table 3. Abundance and functional trait values among those larger-shelled land snail species (adult shell size $\geq 4.0 \mathrm{~mm}$ ) most responsive to intensive management of invasive rats as indicated by sampling in paired forest blocks at nine locations where rats were either intensively managed (T) or not (NT).

\begin{tabular}{|c|c|c|c|c|c|c|}
\hline \multicolumn{4}{|c|}{$\begin{array}{l}\text { Species contributing most to treatment } \\
\text { differences in community-level abundance }\end{array}$} & \multicolumn{3}{|c|}{$\begin{array}{l}\text { Species contributing most to treatment } \\
\text { differences in community-level functional trait values }\end{array}$} \\
\hline Location & Species & $\mathrm{T}$ & NT & Species & $\mathrm{T}$ & NT \\
\hline Trounson & $\begin{array}{l}\text { Phrixgnathus sciadium } \\
\text { Flammulina perdita } \\
\text { Liarea turriculata } \\
\text { Liarea egea } \\
\text { Allodiscus dimorphus }\end{array}$ & $\begin{array}{l}56 \\
66 \\
73 \\
63 \\
84\end{array}$ & $\begin{array}{l}11 \\
22 \\
27 \\
32 \\
37\end{array}$ & $\begin{array}{l}\text { Phenacohelix ziczac } \\
\text { Phrixgnathus sciadium } \\
\text { Flammulina perdita } \\
\text { Liarea egea } \\
\text { Liarea turriculata } \\
\text { Allodiscus dimorphus }\end{array}$ & $\begin{array}{l}227.9 \\
280.8 \\
391.6 \\
339.0 \\
595.6 \\
591.8\end{array}$ & $\begin{array}{c}44.3 \\
45.3 \\
107.2 \\
155.4 \\
198.1 \\
234.3\end{array}$ \\
\hline Waitakere & Phenacohelix giveni & 140 & 48 & $\begin{array}{l}\text { Rhytida greenwoodi } \\
\text { Phenacohelix giveni } \\
\text { Allodiscus dimorphus }\end{array}$ & $\begin{array}{l}469.5 \\
626.2 \\
557.2\end{array}$ & $\begin{array}{l}152.5 \\
191.0 \\
354.6\end{array}$ \\
\hline Moehau & $\begin{array}{l}\text { Phenacohelix giveni } \\
\text { Phrixgnathus poecilosticta }\end{array}$ & $\begin{array}{l}127 \\
147\end{array}$ & $\begin{array}{c}0 \\
78\end{array}$ & $\begin{array}{l}\text { Phenacohelix giveni } \\
\text { Thalassohelix zelandiae } \\
\text { Rhytida greenwoodi }\end{array}$ & $\begin{array}{l}581.8 \\
278.8 \\
307.0\end{array}$ & $\begin{array}{c}0.0 \\
29.4 \\
54.2\end{array}$ \\
\hline Te Urewera & $\begin{array}{l}\text { Flammulina perdita } \\
\text { Laoma mariae } \\
\text { Phenacohelix giveni } \\
\text { Charopa coma }\end{array}$ & $\begin{array}{c}55 \\
44 \\
88 \\
113\end{array}$ & $\begin{array}{c}6 \\
13 \\
51 \\
54\end{array}$ & $\begin{array}{l}\text { Rhytida greenwoodi } \\
\text { Flammulina perdita } \\
\text { Laoma mariae } \\
\text { Thalassohelix zelandiae } \\
\text { Phenacohelix perplexa } \\
\text { Charopa coma }\end{array}$ & $\begin{array}{l}216.7 \\
333.0 \\
279.4 \\
242.1 \\
340.9 \\
471.5\end{array}$ & $\begin{array}{c}16.1 \\
31.1 \\
58.2 \\
80.7 \\
170.4 \\
205.3\end{array}$ \\
\hline Ruakuri & $\begin{array}{l}\text { Flammulina crebriflammis } \\
\text { Suteria ide } \\
\text { Cavellioropa moussoni }\end{array}$ & $\begin{array}{l}126 \\
184 \\
153\end{array}$ & $\begin{array}{l}30 \\
62 \\
67\end{array}$ & $\begin{array}{l}\text { Flammulina crebriflammi } \\
\text { Allodiscus dimorphus } \\
\text { Cavellioropa moussoni } \\
\text { Suteria ide }\end{array}$ & $\begin{array}{r}596.7 \\
430.5 \\
563.0 \\
1180.1\end{array}$ & $\begin{array}{l}129.6 \\
177.3 \\
233.4 \\
313.2\end{array}$ \\
\hline Wharerino & $\begin{array}{l}\text { Flammulina perdita } \\
\text { Cavellia colensoi }\end{array}$ & $\begin{array}{l}76 \\
93\end{array}$ & $\begin{array}{l}23 \\
33\end{array}$ & $\begin{array}{l}\text { Rhytida greenwoodi } \\
\text { Flammulina perdita } \\
\text { Cavellia colensoi } \\
\text { Allodiscus dimorphus }\end{array}$ & $\begin{array}{l}252.8 \\
464.8 \\
427.0 \\
493.9\end{array}$ & $\begin{array}{l}72.2 \\
102.5 \\
131.4 \\
329.2\end{array}$ \\
\hline Pukawa & $\begin{array}{l}\text { Flammulina perdita } \\
\text { Phenacohelix rusticus } \\
\text { Flammulina zebra } \\
\text { Suteria ide }\end{array}$ & $\begin{array}{c}63 \\
105 \\
76 \\
94\end{array}$ & $\begin{array}{l}16 \\
27 \\
29 \\
30\end{array}$ & $\begin{array}{l}\text { Flammulina perdita } \\
\text { Phenacohelix rusticus } \\
\text { Laoma mariae } \\
\text { Flammulina zebra } \\
\text { Suteria ide } \\
\text { Rhytida greenwoodi }\end{array}$ & $\begin{array}{l}393.6 \\
408.2 \\
308.9 \\
388.9 \\
620.7 \\
397.2\end{array}$ & $\begin{array}{c}82.2 \\
89.6 \\
111.9 \\
135.0 \\
139.8 \\
198.6\end{array}$ \\
\hline Boundary Str. & $\begin{array}{l}\text { Charopa coma } \\
\text { Therasia traversi } \\
\text { Phenacohelix giveni }\end{array}$ & $\begin{array}{l}25 \\
25 \\
71\end{array}$ & $\begin{array}{c}4 \\
7 \\
22\end{array}$ & $\begin{array}{l}\text { Therasia traversi } \\
\text { Charopa coma } \\
\text { Phenacohelix giveni }\end{array}$ & $\begin{array}{l}208.5 \\
129.7 \\
337.6\end{array}$ & $\begin{array}{l}16.7 \\
25.3 \\
82.1\end{array}$ \\
\hline Takaka & $\begin{array}{l}\text { Phacussa prousei } \\
\text { Phenacohelix pilula } \\
\text { Charopa coma } \\
\text { Cavellioropa moussoni }\end{array}$ & $\begin{array}{l}30 \\
22 \\
29 \\
90\end{array}$ & $\begin{array}{c}0 \\
5 \\
9 \\
116\end{array}$ & $\begin{array}{l}\text { Phacussa prousei } \\
\text { Rhytida oconnori } \\
\text { Flammulina perdita } \\
\text { Charopa coma } \\
\text { Thalassohelix igniflua } \\
\text { Rhytida patula } \\
\text { Charopidae sp. } 161 \text { (M.126641) } \\
\text { Cavellioropa moussoni }\end{array}$ & $\begin{array}{l}109.6 \\
110.4 \\
159.8 \\
145.6 \\
124.2 \\
280.9 \\
164.2 \\
283.6\end{array}$ & $\begin{array}{c}0.0 \\
0.0 \\
16.0 \\
33.9 \\
41.4 \\
206.0 \\
295.5 \\
414.1\end{array}$ \\
\hline
\end{tabular}

1997; Studholme 2000) and diminished our ability to detect rat management regime effects on the land snail community. On the other hand, being at high elevation Takaka had few rats present except following beech masts.

\section{Potential direct effects of rodents}

There have been numerous studies of rodent diet, including that of ship rat (e.g. Norman 1970; Daniel 1973; Clark 1982; Gales 1982; Sugihara 1997; Cole et al. 2000; Innes 2005; Sweetapple \& Nugent 2007; Pisanu et al. 2011). However, despite land snails being known to be predated by ship rat (e.g. Allen 2004; Towns et al. 2006; Chiba 2007; Meyer \&
Shiels 2009), and indeed predation by ship rats and other Rattus species recognized as a key threatening process (e.g. Meads et al. 1984; Sherley et al. 1998; Bennett et al. 2002; Brescia et al. 2008), the presence of land snails in Rattus stomach and faecal samples has been infrequently reported and as a consequence land snails are often considered as an insignificant dietary component. The limitation of stomach and faecal analyses is well recognized (e.g. Caut et al. 2008; Liat 2009) and in the case of land snail prey their inclusion in the diet of Rattus may be overlooked because shells may be fragmented and discarded during the predation event and thus not ingested, of rapid digestion of digested soft tissues, 
Table 4. RTI for ship rat and Norway rat abundance monitored in paired forest blocks at nine locations where rats were either intensively managed (T) or not (NT), with SES estimated from null models, and level of rat control achieved.

\begin{tabular}{|c|c|c|c|c|c|}
\hline Location & $\begin{array}{l}\text { Number of RTI } \\
\text { assessments }\end{array}$ & $\mathrm{T}$ & $\begin{array}{c}\text { Mean RTI (range) } \\
\text { NT }\end{array}$ & $\mathrm{SES}^{1}$ & $\begin{array}{l}\text { Level of rat control } \\
\% \text { reduction in RTI }\end{array}$ \\
\hline Trounson & 11 & $3.2(0-16)$ & $19.9(7-32)$ & 23.904, $\mathrm{P}<0.001$ & 84 \\
\hline Waitakere & 15 & $7.0(0-37)$ & $41.7(12-70)$ & 61.394, $\mathrm{P}<0.001$ & 83 \\
\hline Moehau & 9 & $11.6(0-29)$ & $75.4(62-90)$ & 63.730, $\mathrm{P}<0.001$ & 84 \\
\hline Te Urewera & 39 & $15.3(0-54)$ & $69.5(42-100)$ & $80.465, \mathrm{P}<0.001$ & 78 \\
\hline Ruakuri & $2^{2}$ & 0 & $35(30-40)$ & & $\sim 100$ \\
\hline Wharerino & 12 & $3.9(0-22)$ & $61.8(30-90)$ & 94.086, $\mathrm{P}<0.001$ & 94 \\
\hline Pukawa & $1^{3}$ & 0 & 27 & & $\sim 100$ \\
\hline Boundary Str. & 52 & $3.1(0-42)$ & $31.2(3-60)$ & 43.539, $\mathrm{P}<0.001$ & 90 \\
\hline Takaka & $0^{4}$ & & & No data & \\
\hline
\end{tabular}

1. Analyses based only on those assessments in which rat tracking rate estimates were made within the same calendar month for treated and non-treated blocks within the location.

2. Only two RTI assessments, and these not undertaken concurrently in treated and non-treated blocks.

3. Single RTI assessment. Absence of rat tracks in tunnels in treated block indicating very low rat abundance was supported by several other assessment methods (King \& Scurr 2013).

4. No RTI assessments. Monitoring in treated block confined to rats taken in kill traps. No monitoring of rats in non-treated block.

and the presence of few post-gastric diagnostic residues. Land snail radular teeth and jaws provide useful post-gastric diagnostic items in diet analyses (e.g. South 1980), but are generally overlooked because of their small size or they are simply not recognized.

That rats may be differentially affecting land snails of different body sizes has important consequences for conservation management, and so it is important to understand the underlying mechanisms. Rats predate on items across a broad prey size range, but, in general, information is lacking on the level of intake of prey below c. $10 \mathrm{~mm}$, especially for soft-bodied prey. The threshold $4 \mathrm{~mm}$ maximum shell dimension used to partition the communities based on potential vulnerability was somewhat arbitrary in the absence of definitive information of accepted and preferred size of prey items. Nonetheless, it should be recognized that snails as prey would assume a larger size when active than indicated by the shell maximum dimension, as the animals extend their head/ foot from the shell aperture for locomotor activity. For example, a species with a shell diameter of $4 \mathrm{~mm}$ may assume a length of c. $8 \mathrm{~mm}$ when actively moving about during foraging and other activities.

The higher potential vulnerability of the larger snails assumed in this study was based on the expectation that these snails are more apparent to searching predators, in part because snail nocturnal activity occurs on the surface of the litter mass. In contrast, micro-snails are primarily active within the litter mass. Whether rats reject micro-snails as diet items because of the small return on search and handling effort is not known. The absence of an effect of rat management regime on microsnails may be related to their inherently higher rate of increase, compared to larger-bodied snails, because of higher densities and shorter generation times. Nonetheless, per capita rate of increase in many micro-snails may be low as fecundity is constrained by the low shell volume necessitating production of eggs either singly or in small clutches (Heller 2001). While at least some larger New Zealand land snails are considered $K$-selected species (Barker 2005) in being long-lived and producing a few large, well-resourced eggs, there is currently little information on the life-history strategies for the great majority of New Zealand land snails.

\section{Potential indirect effects}

That responses evidently occurred in relatively small-sized snails raises the possibility that effects were indirect, either mediated through the activity of ship rat or through some secondary effect of the rat management regimes.

Introduced animals can exert indirect effects through trophic cascades and habitat modifications (O'Dowd et al. 2003; Sanders et al. 2003; Croll et al. 2005; Green et al. 2011), including effects on the microorganisms that drive decomposition processes (e.g. Fukami et al. 2006; Eisenhauer et al. 2011; Peay et al. 2012). As a consequence, attribution of responses is particularly problematic when the pest under management, such as ship rat, is an omnivore since its removal may lead to numerous changes in ecosystem properties additional to release from predation. The great majority of the land snail species studied here were detritivores, feeding on decaying plant material and the associated decomposer microorganisms. The few predatory land snail species present fed on either these detritivore snails or other invertebrates of the decomposer web, such as earthworms. It is thus possible that the responses documented in this study were due in part to changes in the resource base when ship rats were reduced in abundance.

Interpretation is further complicated if multiple pest species are controlled (Veltman 2000) and if regard is not given to the whole-community context of the species removal (Zavaleta et al. 2001), including such possible outcomes as meso-predator release (e.g. Rayner etal. 2007; Harper \& Cabrera 2010; Ruscoe et al. 2011). At the majority of locations included in the present study, several pest mammals - including mustelids, deer, pigs, and possums - were under management in addition to ship rats. Reduced abundance of these mammal species may have affected the land snail communities. For example, Wardle et al. (2001) demonstrated that fences to exclude browser mammals such as deer led to marked changes in communities of most groups of litter-dwelling meso- and macro-faunas, including land snails, mediated primarily by changes in the disturbances of the litter layer and ground-cover vegetation. The forest blocks sampled in the present study exhibited no obvious differences in vegetation composition or litter composition and depth - unlike the long-fenced exclosures 
sampled by Wardle et al. (2001) - and any differential effects of deer and possums might be excluded from consideration. Nonetheless, in-depth assessments of neither deer and possum numbers nor vegetation condition were made and therefore such mechanisms of effect cannot be entirely excluded. Differences in abundances and herbivory of deer and possum may have meant some sites were more responsive to rat management rimes than others. It is also unclear as to the level of effect the rat management regimes had on abundance of mammals such as house mouse and hedgehog, both of which predate on invertebrates, including land snails (Allen 2004), and are pervasive in New Zealand forests.

\section{Conclusion}

Previous studies have not yielded unequivocal evidence of benefit to invertebrates from management of rodents in New Zealand forest systems, although no previous studies have specifically examined the benefits to land snail communities. The evidence for response in the land snail communities to management of ship rat and Norway rat to low levels argues for a reassessment of both the ecological importance of these invasive mammals in New Zealand forest systems and how we might best resolve their impact on invertebrates.

The present study indicated that measuring invertebrate community responses to the removal or reduction of a pest mammal can give some indication of the strength of interactions between the species involved. However, the complexities of multi-trophic community dynamics may mask important effects on component groups of species and the mechanisms driving such responses may be invisible, unless the pest control is conducted as an experimental setting and accompanied by detailed ecological research. When assessing effects of disturbance such as predation by rats, or conversely ecological release when that disturbance is removed, consideration must be given to the dependency of population dynamics in indigenous species on the level of irreplaceable mortality (Thompson 1955; Morris 1965; Buonaccorsi \& Elkinton 1990; Schneider 2011) imposed by the predatory activities of rats. That is, it is critical to establish if rats impose mortality that cannot be compensated for by variation in the intensity of contemporaneous or subsequent mortality factors operating in the populations. As a research approach, rather than determining community-level responses, it may be more informative to determine the dynamics of populations of individual indigenous species through analyses of life tables and regulatory or density dependent actions of individual mortality factors, under forest management regimes that provide contrasting abundances of rats. A stratified subset of indigenous species might be selected to span the range of potential vulnerabilities to rodent predation and to rodent perturbations of other ecosystem processes.

In respect to land snails, most current conservation efforts in New Zealand focus on large sized species. This approach has been justified on the demonstrated high risk to exotic predatory mammals in the larger species and the perceived much lower risk in micro-snails. The present work is the first real data available on the topic of risk in the micro-snail component of the communities. While the precise mechanisms await clarification, this study indicates a much lower risk in the micro-snails and thus supports current practice.

\section{Acknowledgements}

This research was supported by the Foundation for Research, Science and Technology under Contract CO9X0503. I thank the Department of Conservation, Pukawa Wildlife Management Trust, Royal Forest and Bird Protection Society and Auckland Regional Council for providing access to, and sharing information on forest areas at which management of ship rats were in progress. Daniel Baigent, Laurence Barea, Tony Beauchamp, Steve Bolton, Dave Carlton, Lisa Daglish, Denise Fastier, Mike Ogle, Oliver Overdyck, Nick Poutu, Abi Quinnell, Dave Smith, Lindsay Wilson (all Department of Conservation), Jean Stanley (Pukawa Wildlife Management Trust), and John Sumich (Ark in the Park, Waitakere Ranges) provided various forms of logistic support, including consultation with iwi and collection permits. This work was conducted under New Zealand Department of Conservation (DOC) Global Concession CA-5160-OTH. Mike Ogle and Lisa Daglish kindly provided assistance in the field. An earlier draft of the manuscript benefited from the critical comments by John Innes, Kath Walker and an anonymous reviewer.

\section{References}

Albano PG 2014. Comparison between death and living land mollusk assemblages in six forested habitats in northern Italy. Palaios 29: 338-347.

Allen JA 2004. Avian and mammalian predators of terrestrial gastropods. In: Barker GM ed Natural enemies of terrestrial molluscs. Wallingford, United Kingdom, CABI Publishing. Pp. 1-36.

Atkinson IAE 2001. Introduced mammals and models for restoration. Biological Conservation 99: 81-96.

Barker GM 2005. The character of the New Zealand land snail fauna and communities: some evolutionary and ecological perspectives. Records of the Western Australian Museum, Supplement 68: 53-102.

Barker GM, Mayhill PC 1999. Patterns of diversity and habitat relationships in terrestrial mollusc communities of the Pukeamaru Ecological District, northeastern New Zealand. Journal of Biogeography 26: 215-238.

Bennett SJ, Standish RJ, Stringer IAN 2002. Effects of rodent poisoning on Powelliphanta traversi. Science for Conservation 195C. Wellington, Department of conservation. $16 \mathrm{p}$.

Blackwell GL 2005. Another world: the composition and consequences of the introduced mammal fauna of New Zealand. Australian Zoologist 33: 108-118.

Bray JR, Curtis JT 1957. An ordination of the upland forest communities of southern Wisconsin. Ecological Monographs 27: 325-349.

Brescia FM, Pöllabauer CM, Potter MA, Robertson AW 2008. A review of the ecology and conservation of Placostylus (Mollusca: Gastropoda: Bulimulidae) in New Caledonia. Molluscan Research 28: 111-122.

Buckley TR, Krosch M, Leschen RAB 2015. Evolution of New Zealand insects: summary and prospectus for future research. Austral Entomology 54: 1-27.

Buonaccorsi JP, Elkinton JS 1990. Estimation of contemporaneous mortality factors. Researches in Population Ecology 32: 151-171.

Cameron RAD, Pokryszko BM 2005. Estimating the species richness and composition of land mollusc communities: 
problems, consequences and practical advice. Journal of Conchology 38: 529-548.

Campbell-Hunt D 2008. Community-driven ecological restoration in New Zealand. Pacific News 30: 12-15.

Caut S, Angulo E, Courchamp F 2008. Dietary shift of an invasive predator: rats, seabirds and sea turtles. Journal of Applied Ecology 45: 428-437.

Chao A 1984. Non-parametric estimation of the number of classes in a population. Scandinavian Journal of Statistics 11: 265-270.

Chao A 1987. Estimating the population size for capturerecapture data with unequal catchability. Biometrics 43: 783-791.

Chao A, Chazdon RL, Colwell RK, Shen T-J 2005. A new statistical approach for assessing compositional similarity based on incidence and abundance data. Ecology Letters 8: $148-159$.

Chiba S 2007. Morphological and ecological shifts in a land snail caused by the impact of an introduced predator. Ecological Research 22: 884-891.

Clark DA 1982. Foraging behavior of a vertebrate omnivore (Rattus rattus): meal structure sampling, and diet breadth. Ecology 63: 763-772.

Cole FR, Loope LL, Medeiros AC, Howe CE, Anderson LJ 2000. Food habits of introduced rodents in high-elevation shrubland of Haleakala National Park, Maui, Hawaii. Pacific Science 54: 313-329.

Colwell RK, Coddington JA 1994. Estimating terrestrial biodiversity through extrapolation. Philosophical Transactions of the Royal Society (Series B) 345: 101-118.

Craddock P 1997. Effect of rodent control on invertebrate communities in coastal forest nearAuckland. Unpublished MSc thesis. Auckland, New Zealand, University of Auckland. $132 \mathrm{p}$.

Croll DA, Maron JL, Estes JA, Danner EM, Byrd GV 2005. Introduced predators transform subarctic islands from grassland to tundra. Science 307: 1959-1961.

Daniel MJ 1973. Seasonal diet of the ship rat (Rattus r. rattus) in lowland forest in New Zealand. Proceedings of the New Zealand Ecological Society 20: 21-30.

Douglas DD, Brown DR, Pederson N 2013. Land snail diversity can reflect degrees of anthropogenic disturbance. Ecosphere 4(2): 1-14.

Eisenhauer N, Schlaghamerský J, Reich PB, Frelich LE 2011. The wave towards a new steady state: effects of earthworm invasion on soil microbial functions. Biological Invasions 13: 2191-2196.

Fukami T, Wardle DA, Bellingham PJ, Mulder CP, Towns DR, Yeates GW, Bonner KI, Durrett MS, Grant-Hoffman MN, Williamson WM 2006. Above- and below-ground impacts of introduced predators in seabird-dominated island ecosystems. Ecology Letters 9: 1299-1307.

Gales RP 1982. Age- and sex-related differences in diet selection by Rattus rattus on Stewart Island, New Zealand. New Zealand Journal of Zoology 9: 463-466.

Gibbs GW 1998. Why are some weta (Orthoptera: Stenopelmatidae) vulnerable yet others are common? Journal of Insect Conservation 2: 161-166.

Gibbs GW 2009. The end of an 80-million year experiment: a review of evidence describing the impact of introduced rodents on New Zealand's 'mammal-free' invertebrate fauna. Biological Invasions 11: 1587-1593.

Gibbs GW 2010. Do New Zealand invertebrates reflect the dominance of birds in their evolutionary history? New
Zealand Journal of Ecology 34: 152-157.

Gillies CA, Williams D 2013. DOC tracking tunnel guide v2.5.2: using tracking tunnels to monitor rodents and mustelids. Inventory and monitoring toolbox: animal pests DOCDM-1199768. Hamilton, New Zealand, Department of Conservation, Science \& Capability Group. 14 p.

Gotelli NJ, McCabe DJ 2002. Species co-occurrence: a metaanalysis of J. M. Diamond's assembly rules model. Ecology 83: 2091-2096.

Gotelli NJ, Entsminger GL2004. EcoSim: null models software for ecology. Version 7. Jericho, Vermont, Acquired Intelligence Inc. \& Kesey-Bear. http://garyentsminger. com/ecosim/index.htm.

Green C 2002. Recovery of invertebrate populations on Tiritiri Matangi Island, New Zealand following eradication of Pacific rats (Rattus exulans). In: Veitch CR, Clout MN eds Turning the tide: the eradication of invasive species. Gland, Switzerland, and Cambridge, UK, IUCN SSC Invasive Species Specialist Group. Pp. 407.

Green PT, O'Dowd DJ, Abbott KL, Jeffery M, Retallick K, Mac Nally R 2011. Invasional meltdown: invader-invader mutualism facilitates a secondary invasion. Ecology 92: 1758-1768.

Harper GA, Cabrera LF 2010. Response of mice (Mus musculus) to the removal of black rats (Rattus rattus) in arid forest on Santa Cruz Island, Galápagos. Biological Invasions 12: 1449-1452.

Heller J 2001. Life history strategies. In: Barker GM ed The biology of terrestrial Mollusca. Wallingford, UK, CAB International. Pp. 413-445.

Hunt M, Sherley G[H], Wakelin M 1998. Results of a pilot study to detect benefits to large-bodied invertebrates from sustained regular poisoning of rodents and possums at Karioi, Ohakune. Science for Conservation 102. Wellington, New Zealand, Department of Conservation. $18 \mathrm{p}$.

Innes JG 2005. The ship rat. In: King CM ed The handbook of New Zealand mammals. 2nd edn. Melbourne, Oxford University Press. Pp. 187-203.

Innes J[G], Williams D 1991. The impact of aerial 1080 poisoning on ship rat populations at Mapara and Kaharoa. Forest Research Institute contract report FWE 91/30. Rotorua, New Zealand, Forest Research Institute. 7 p.

Innes J[G], Warburton B, Williams D, Speed H, Bradfield P 1995. Large-scale poisoning of ship rats (Rattus rattus) in indigenous forests of the North Island, New Zealand. New Zealand Journal of Ecology 19: 5-17.

King CM, Edgar RL 1977. Techniques for trapping and tracking stoats (Mustela erminea): a review, and a new system. New Zealand Journal of Zoology 4: 193-212.

King CM, Moller H 1997. Distribution and response of rats (Rattus rattus, $R$. exulans) to seedfall in New Zealand beech forests. Pacific Conservation Biology 3: 143-155.

King PA 2007. The effects of rodents on ground dwelling arthropods in the Waitakere Ranges. Unpublished MSc thesis. Auckland, New Zealand, Auckland University of Technology. 179 p.

Kuschel G, Worthy TH 1996. Past distribution of large weevils (Coleoptera: Curculionidae) in the South Island, New Zealand, based on Holocene fossil remains. The New Zealand Entomologist 19: 15-19.

Leathwick, JR, Stephens RTT 1998. Climate surfaces for New Zealand. Landcare Research Contract Report LC9798 126. Hamilton, New Zealand, Landcare Research. 22 p. 
Leprieur F, Albouy C, De Bortoli J, Cowman PF, Bellwood DR, Mouillot D 2012. Quantifying phylogenetic beta diversity: distinguishing between 'true' turnover of lineages and phylogenetic diversity gradients. PLoS ONE 7(10): DOI: 10.1371/journal.pone.0042760.

Leschen RAB, Rhode BE 2002. A new genus and species of large extinct Ulodidae (Coleoptera) from New Zealand. The New Zealand Entomologist 25: 57-64.

Leschen RAB, Marris JWM, Emberson RM, Nunn J, Hitchmough RA, Stringer IAN 2012. The conservation status of New Zealand Coleoptera. The New Zealand Entomologist 35: 91-98.

Liat LB 2009. Land molluscs as food of Malayan rodents and insectivores. Journal of Zoology 148: 554-560.

Lydeard C, Cowie RH, Ponder WF, Bogan AE, Bouchet P, Clark SA, Cummings KS, Frest TJ, Gargominy O, Herbert DG, Hershler R, Perez KE, Roth B, Seddon M, Strong ES, Thompson FG 2004. The global decline of nonmarine mollusks. BioScience 54: 321-330.

Meads MJ, Walker KJ, Elliott GP 1984. Status, conservation and management of the land snails of the genus Powelliphanta (Mollusca: Gastropoda). New Zealand Journal of Zoology 11: 277-306.

MeyerWM, Shiels AB 2009. Black rat(Rattus rattus) predation on non-indigenous snails in Hawai' $\mathrm{i}$ : complex management implications. Pacific Science 63: 339-347.

Morris RF 1965. Contemporaneous mortality factors in population dynamics. Canadian Entomologist 97: 1173-1184.

Norman FI 1970. Food preferences of an insular population of Rattus rattus. Journal of Zoology, London 162: 493-503.

O'Dowd DJ, Green PT, Lake PS 2003. Invasional 'meltdown' on an oceanic island. Ecology Letters 6: 812-817.

Ogden J, Gilbert J 2009. Prospects for the eradication of rats from a large inhabited island: community based ecosystem studies on Great Barrier Island, New Zealand. Biological Invasions 11: 1705-1717.

Peay KG, Dickie IA, Wardle DA, Bellingham PJ, Fukami T 2012. Rat invasion of islands alters fungal community structure, but not wood decomposition rates. Oikos 112: 258-264.

Peters MA, Hamilton D, Eames C 2015. Action on the ground: a review of community environmental groups' restoration objectives, activities and partnerships in New Zealand. New Zealand Journal of Ecology 39: 179-189.

Pisanu B, Caut S, Gutjahr S, Vernon P, Chapuis JL 2011. Introduced black rats Rattus rattus on Ile de la Possession (Iles Crozet, Subantarctic): diet and trophic position in food webs. Polar Biology 34: 169-180.

Ramsay GW 1978. A review of the effect of rodents in New Zealand nature reserves. In: Dingwell PR, Atkinson IAE, Hay $\mathrm{C}$ eds The ecology and control of rodents in New Zealand. Information series 4. Wellington, New Zealand, Department of Lands and Survey. Pp. 89-95.

Rate SR 2009. Does rat control benefit forest invertebrates at Moehau, Coromandel Peninsula? DOC Research \& Development Series 316. Wellington, New Zealand, Department of conservation. $26 \mathrm{p}$.

Rayner MJ, Hauber ME, Imber MJ, Stamp RK, Clout MN 2007. Spatial heterogeneity of mesopredator release within an oceanic island system. Proceedings of the National Academy of Sciences USA 104: 20862-20865.

Rufaut CG, Gibbs GW 2003. Response of a tree weta population (Hemideina crassidens) after eradication of the Polynesian rat from a New Zealand island. Restoration Ecology 11: 13-19.

Ruscoe WA, Ramsey DSL, Pech RP, Sweetapple PJ, Yockney I, Barron MC, Perry M, Nugent G, Carran R, Warne R, Brausch C, Duncan RP2011. Unexpected consequences of control: competitive vs. predator release in a four-species assemblage of invasive mammals. Ecology Letters 14: 1035-1042.

Ruscoe WA, Sweetapple PJ, Perry M, Duncan RP2013. Effects of spatially extensive control of invasive rats on abundance of native invertebrates in mainland New Zealand forests. Conservation Biology 27: 74-82.

Russell JC, Innes JG, Brown PH, Byrom AE 2015. Predatorfree New Zealand: conservation country. BioScience 65: 520-525.

Sanders NJ, Gotelli NJ, Heller NE, Gordon DM 2003. Community disassembly by an invasive ant species. Proceedings of the National Academy of Sciences USA 100: 2474-2477.

Saunders A, Norton DA 2001. Ecological restoration at mainland islands in New Zealand. Biological Conservation 99: 109-119.

Schilthuizen M 2011. Community ecology of tropical forest snails: 30 years after Solem. Contributions to Zoology 80: $1-15$.

Schneider JC 2011. Irreplaceable mortality: is it? Environmental Entomology 40: 1341-1344.

Sherley GH, Stringer IAN, Parrish GR, Flux I 1998. Demography of two landsnail populations (Placostylus ambagiosus, Pulmonata: Bulimulidae) in relation to predator control in the far north of New Zealand. Biological Conservation 84: 83-88.

Shipley B, Vile D, Garnier E 2006. From plant traits to plant communities: a statistical mechanistic approach to biodiversity. Science 314: 812-814.

Sinclair L, McCartney J, Godfrey J, Pledger S, Wakelin M, Sherley $\mathrm{G}[\mathrm{H}]$ 2005. How did invertebrates respond to eradication of rats from Kapiti Island, New Zealand? New Zealand Journal of Zoology 32: 293-315.

Sólymos P, Kemencei Z, Páll-Gergely B, Farkas R, Vilisics F, Hornung E 2009. Does shell accumulation matter in micro-scale land snail surveys? Malacologia 51:389-393.

South A 1980. A technique for the assessment of predation by birds and mammals on the slug Deroceras reticulatum (Muller) (Pulmonata, Limacidae). Journal of Conchology 30: 229-235.

Spencer HG, Marshall BA, Maxwell PA, Grant-Mackie JA, Stilwell JD, Willan RC, Campbell HJ, Crampton JS, Henderson RA, Bradshaw MA, Waterhouse JB, Pojeta J 2009. Phylum Mollusca: chitons, clams, tusk shells, snails, squids, and kin. In: Gordon DP ed New Zealand inventory of biodiversity: 1. Kingdom Animalia: Radiata, Lophotrochozoa, Deuterostomia. Christchurch, New Zealand, Canterbury University Press. Pp. 161-254

StringerIAN, Hitchmough RA2012. Assessing the conservation status of New Zealand's native terrestrial invertebrates. The New Zealand Entomologist 35: 77-84.

Studholme B 2000. Ship rat (Rattus rattus) irruptions in South Island beech (Nothofagus) forest. Conservation Advisory Science Notes No. 318. Wellington, Department of Conservation. $9 \mathrm{p}$.

Sugihara RT 1997. Abundance and diets of rats in two Hawaiian forests. Pacific Science 51: 189-198.

Sweetapple PJ, Nugent G 2007. Ship rat demography and diet 
following possum control in a mixed podocarp-hardwood forest. New Zealand Journal of Ecology 31: 186-201.

Thompson WR 1955. Mortality factors acting in a sequence. Canadian Entomologist 87: 264-275.

Towns DR, Atkinson IAE, Daugherty CH 2006. Have the harmful effects of introduced rats on islands been exaggerated? Biological Invasions 8: 863-891.

Veltman C 2000. Do native wildlife benefit from possum control? In: Montague TL ed The brushtail possum. Lincoln, New Zealand, Manaaki Whenua Press. Pp. 241-250.

Warburton B 1989. The effect of a routine aerial 1080 poison operation on rat numbers. Report prepared for Department ofConservation, Wellington, New Zealand. Christchurch, New Zealand. Forest Research Institute. 14 p.

Wardle DA, Barker GM, Yeates GW, Bonner KI, GhaniA2001. Introduced browsing mammals in natural New Zealand forests: aboveground and belowground consequences. Ecological Monographs 71: 587-614.

Watts CH 2004. Ground-dwelling beetles in Karori Wildlife Sanctuary before and after mammal pest eradication. Landcare Research Contract Report LC 0304. Hamilton, New Zealand, Landcare Research. 126 p.

Editorial board member: Isabel Castro

Received 4 September 2015; Accepted 9 April 2016

\section{Supplementary Material}

Additional supporting information may be found in the online version of this article:

Table S1. Forest sites sampled in New Zealand, with information on location, treatment, NZMG coordinates, elevation, and vegetation.

Table S2. Land snail species recorded in samples from forest blocks at nine locations in New Zealand, with family, biostatus, and shell size.

Table S3. Sources of data on rat tracking index (RTI) for ship rat and Norway rat abundance monitored in paired forest blocks at nine locations where rats were either intensively managed (T) and not (NT).

Table S4. Community-level metrics for land snails sampled in paired forest blocks at nine locations in which rats were either intensively managed (T) and not (NT).
Watts C[H], Thornburrow D, Cave V, Innes J[G] 2014. Beetle community changes following pest mammal control at two biodiversity sanctuaries in Wellington, New Zealand, Journal of the Royal Society of New Zealand 44: 61-87.

Wilmshurst JM, Anderson AJ, Higham TGF, Worthy TH 2008. Dating the late prehistoric dispersal of Polynesians to New Zealand using the commensal Pacific rat. Proceedings of the National Academy of Sciences 105: 7676-7680.

Worthy TH, Tennyson AJD, Archer M, Musser AM, Hand SJ, Jones C, Douglas BJ, McNamara JA, Beck RMD 2006. Miocene mammal reveals a Mesozoic ghost lineage on insular New Zealand, southwest Pacific. Proceedings of the National Academy of Sciences of the United States of America 103: 19419-19423.

Yanes Y 2011. Shell taphonomy and fidelity of living, dead, Holocene, and Pleistocene land snail assemblages. Palaios 27: $127-136$.

Zavaleta ES, Hobbs RH, Mooney HA 2001. Viewing invasive species removal in a whole-ecosystem context. Trends in Ecology and Evolution 16: 454-459.

Table S5. Whole community-level diversity and functional traits for all (empty and 'live collected') land snails sampled in paired forest blocks at nine locations in which rats were either intensively managed (T) and not(NT), with Standardized Effect Size estimated from null models.

Figure S1. Individual-based rarefaction curves showing the cumulative number of 'live-collected' land-snail species at nine locations in which rats were either intensively managed (T) and not (NT).

The New Zealand Journal of Ecology provides online supporting information supplied by the authors where this may assist readers. Such materials are peer-reviewed and copy-edited but any issues relating to this information (other than missing files) should be addressed to the authors. 